\title{
Reabilitation of a wastewater treatment plant - possible environment impact
}

\author{
Mădălina Stănescu, Constantin Buta, Geanina Mihai
}

\begin{abstract}
Romania, has declared, by the Governmental Decision nr.352/2005, all its territory as a sensitive area. This implies that, for all urban agglomerations larger than 10.000 population equivalent waste water treatment plants (WWTP) with nutrient removal must be built or upgraded.

This paper presents the results regarding the possible environmental impacts expected from the project for construction of waste water treatment plant in the City of Vaslui, with main focus on surface water.

This research study includes assessment methodology, project description regarding the rehabilitation and extension of the Vaslui waste water treatment plant, data related to water resources, impact assessment on water and appropriate mitigation measures. The assessment of the impacts has been performed for the construction and operational phase of the wastewater treatment plant. The construction phase was subdivided into several phases, while in the operational phase the impacts are analyzed following the line for treatment of the wastewater and effluent production, the line for sludge production and drying process, sludge disposal in safety conditions considering the provisions of 86/278/EEC Directive and the line for biogas utilization.
\end{abstract}

Keywords - waste water treatment plant, surface water, environmental risk, mitigation measures

\section{INTRODUCTION}

Water is known as an essential element of life, so if we want to enjoy it, we should treat as it deserve, whether the population will increase to that point where it says, we will not have the necessary resources.

Manuscript received $6^{\text {th }}$ of October 2017

Mădălina Stănescu - OvidiusUniversity of Constantza, Civil Engineering Faculty, Romania, (corresponding author phone: +40-241-619040; fax: +40-241-618372; e-mail: madalina.stanescu79@gmail.com) and S.C. SAM Proiect \& Management S.R.L.

Constantin Buta and Geanina Mihai - OvidiusUniversity of Constantza, Civil Engineering Faculty, Romania 
European Union issued on October 23, 2000 the Directive 2000/60/EC Framework through which she wanted to create a framework for Community Water. This Directive aims several objectives, such as preventing and reducing pollution, promoting sustainable water use, protect the environment, improve the status of aquatic ecosystems and mitigate the effects of floods and droughts.

Surface water quality is influenced by wastewater discharges, when they are not pre-treated or inadequately treated before being discharged into the receiver. The annual statistics on the main water sources in Romania and the synthesis of water quality in Romania, produced annually in the period 2007-2011 by the "Romanian Waters" National Administration estimated that the total volume of wastewater derived from human agglomerations and sufficiently purified which was evacuated in natural receptors increased by 43.925 million $\mathrm{m}^{3} /$ year $(14.6 \%)$.

The impact of pollution sources on the receiving waters depends on the water flow rate and pollutant load. Wastewater pollutant load from urban areas have the greatest impact on the load of organic substances, materials in suspension, nutrients, detergents and extractable substances.

\subsection{The legal base}

Council Directive 91/271/EEC of May 2, 1991 concerning urban waste water treatment, as amended by Commission Directive 98/15/EC on February 27, 1998, is the legal basis of community legislation in the field of wastewater. Directive 91/271/EEC concerning urban wastewater has been fully transposed into Romanian legislation by Government Decisionno.188/2002 to approve the norms discharge of wastewater into the aquatic environment, as amended by Government Decision no. $352 / 2005$.

The central aim of the directive is to protect the environment from the adverse effects of discharges of urban waste and waste water from certain industrial sectors (mainly from the processing and manufacture of the food industry).

In Romania, the European legislation in the field of wastewater treatment and discharge into the aquatic environment was implemented during 2002-2005, but further implementing steps are required in order to fully comply, the requirements of the Directive.

Taking into consideration the position of Romania in the Danube basin and also in the Black Sea basin and the need for environmental protection in these areas, Romania declared its entire territory as sensitive area. This decision is reflected in the fact that agglomerations with more than 10,000 equivalent inhabitants must provide an infrastructure for urban wastewater treatment enabling advanced treatment, especially in terms of the nutrients nitrogen and phosphorus - GD no.352/2005 $\operatorname{art.3(1).~}$

The implementation deadline of the Directive varies and depends on the size of the agglomeration and its impact on the receiving waters.

Final transition deadline for implementation of the Directive has been set at December 31, 2018, with intermediate deadlines for collection and treatment of urban wastewater. 
Achievements of intermediate targets for biodegradable load expressed in equivalent inhabitants in terms of urban wastewater treatment are:

- December 31, 2010 - representing $51 \%$ of the total biodegradable load in equivalent inhabitants;

- December 31, 2013 - representing $61 \%$ of the total biodegradable load in equivalent inhabitants;

- December 31, 2015 - representing $77 \%$ of the total biodegradable load on equivalent inhabitants.

\subsection{Current situation}

Based on the Implementation Plan of the Directive 91/271/EEC concerning urban wastewater treatment were estimated the number of agglomerations discharging wastewater into water resources and their size.

According to the provisions of the Directive the treatment level is defined by the load size of the entire agglomeration, and the type and quality of the water course at the point of discharge. Given the compliance deadlines set by the Accession Treaty were established the following agglomerations which must be equipped with wastewater treatment systems (Table 1).

Table 11 The projected situation of waste water treatment plant (WWTP) until the implementation deadline of the Directive

\begin{tabular}{|c|c|c|c|c|c|c|}
\hline \multirow{2}{*}{ Year } & \multicolumn{2}{|c|}{ Surface waters } & \multicolumn{2}{c|}{ Coastal waters } & \multicolumn{2}{c|}{ Total } \\
\cline { 2 - 7 } & $\begin{array}{c}\text { ggglome } \\
\text { rations }\end{array}$ & $\begin{array}{c}\text { equivalent } \\
\text { inhabitants }\end{array}$ & $\begin{array}{c}\text { Agglome } \\
\text { rations }\end{array}$ & $\begin{array}{c}\text { equivalent } \\
\text { inhabitants }\end{array}$ & $\begin{array}{c}\text { Agglome } \\
\text { rations }\end{array}$ & $\begin{array}{c}\text { equivalent } \\
\text { inhabitants }\end{array}$ \\
\hline 2010 & 232 & 11824532 & 7 & 714080 & 239 & 12538612 \\
\hline 2013 & 95 & 2684817 & 1 & 62472 & 96 & 2747289 \\
\hline 2015 & 525 & 4001462 & 2 & 55046 & 527 & 4056508 \\
\hline 2018 & 1749 & 6176253 & 1 & 3927 & 1750 & 6180180 \\
\hline Total & $\mathbf{2 6 0 1}$ & $\mathbf{2 4 6 8 7 ~ 0 6 5}$ & $\mathbf{1 1}$ & $\mathbf{8 3 5 5 2 5}$ & $\mathbf{2 6 1 2}$ & $\mathbf{2 5 5 2 2 5 9 0}$ \\
\hline
\end{tabular}

According to the report entitled "Status of construction works for urban wastewater treatment and capacity placed in service execution and agglomerations "by the "Romanian Waters" National Administration, in agglomerations with 2000 10000 equivalent inhabitants their degree of connection to the urban WWTP increased from $3.95 \%$ in 2007 to $7.56 \%$ in 2011.

In 2011 have been identified 511 treatment plants (Figure 1). Only 16 treatment plants comply with the requirements of Directive 91/271/EEC, for the second stage of waste water treatment. 


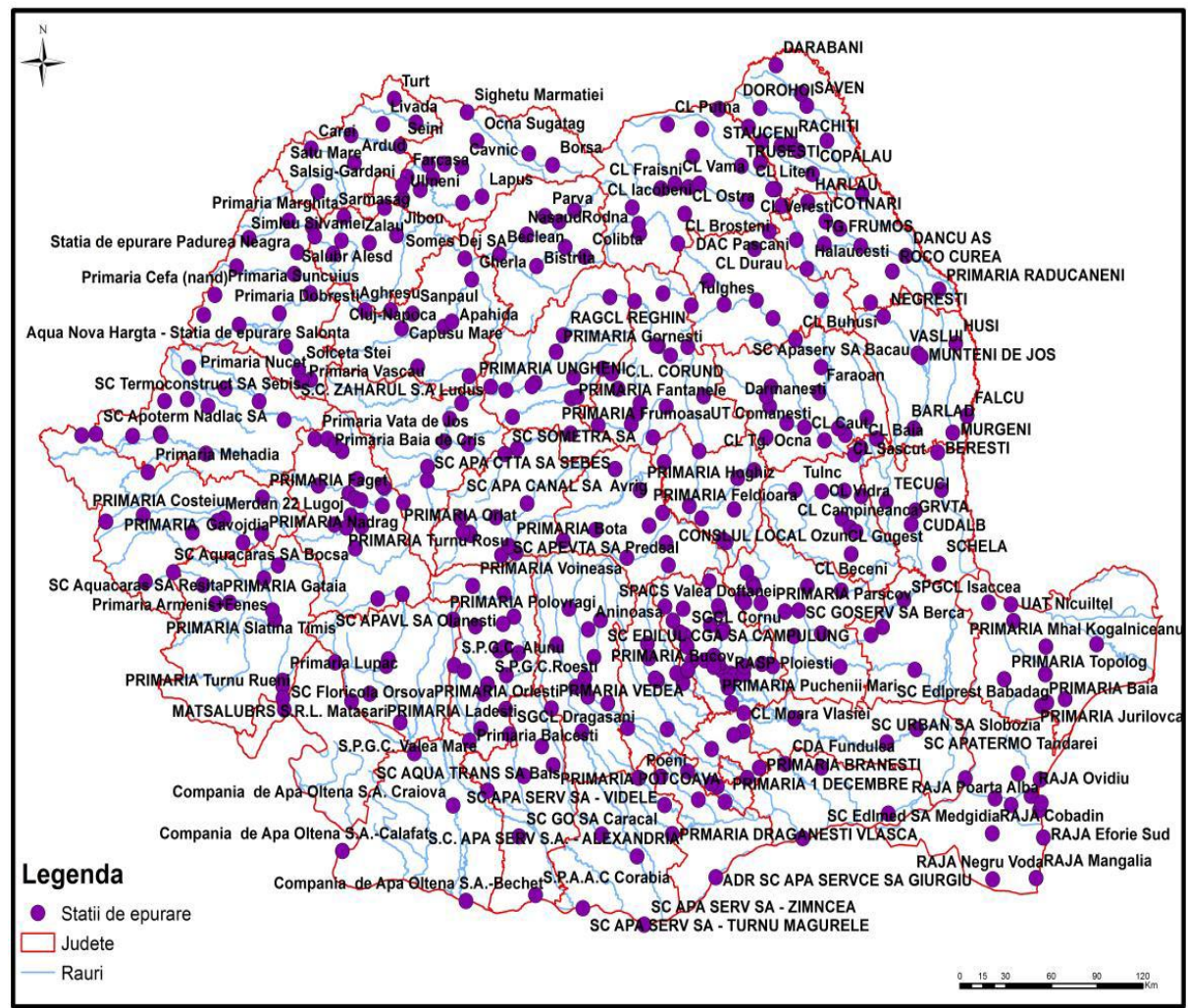

Fig.1. Agglomerations (> 2000 equivalent inhabitants) and the coverage degree with wastewater treatment plants on the Romanian territory in 2011

\section{VASLUI WWTP PROJECT DESIGN}

\subsection{Project description. The existing situation}

Existing WWTP, designed in the early 1980s, was conceived only to reduce suspended solids and BOD5 (CBO5) and was built in two stages, as follows:

- between the years 1970-1974 the first line was built with a capacity of $200 \mathrm{l} / \mathrm{s}$;

- between the years 1986-1989 the second line was built with a capacity of $400 \mathrm{l} / \mathrm{s}$. The current technology for wastewater treatment includes:

- mechanical treatment stage of wastewater;

- biological treatment stage of wastewater;

- Sludge treatment facilities;

- the auxiliary works. 


\subsection{Project description. The situation proposed}

Due to the necessity to improve the quality of treated water and in order to comply the actual standards from the EU and those from Romania, the Vaslui WWTP will be rehabilitated and expanded, so the quality parameters of the effluent will be meet the requirements of standards.

WWTP will include mechanical treatment, biological treatment with activated sludge for tertiary treatment, anaerobic sludge stabilization and biogas use, nitrification, denitrification, mechanical dehydration and thickening equipment for sludge and sludge storage area (Figure 2).

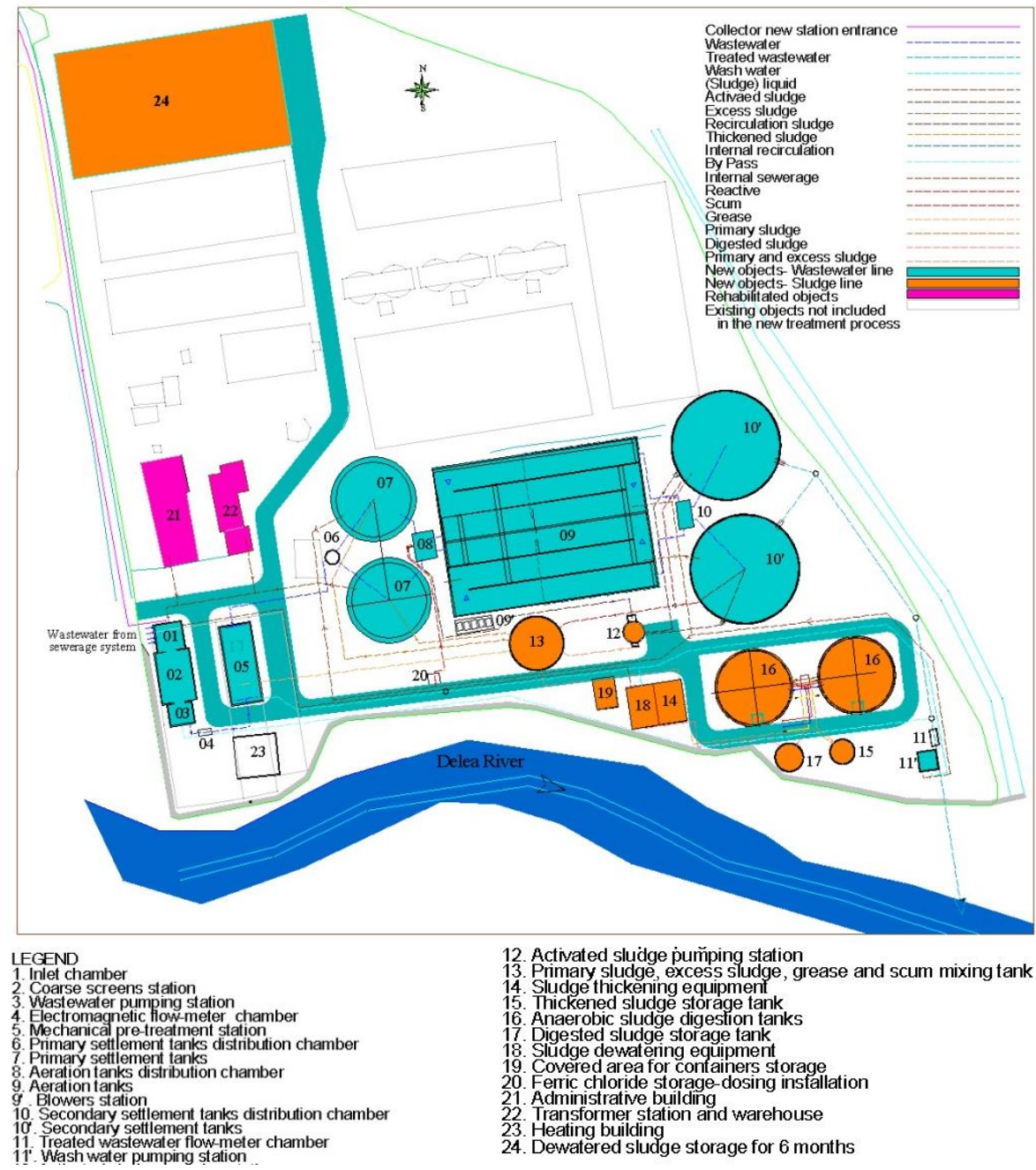

Fig.2. Vaslui WasteWater Treatment Plant - Proposed situation 
In accordance with the EU91/271/EEC directives, it is considered the standards requirements regarding treatment for $\mathrm{BOD}, \mathrm{COD}$, suspended solids, total nitrogen and total phosphorus.

Vaslui WWTP is designed to provide high efficiency in terms of suspension solids removal, organic load, nitrogen and phosphorus for meeting the requirements, in accordance with EU91/271/EEC Directives and with treatment standards.

Modernization and expansion works will be performed on the current location of the wastewater treatment plant. Fenced area is approximately $52.000 \mathrm{sqm}$.

Technologically, the treatment plant is a mechanical-biological wastewater treatment plant, developed on two lines, having a capacity of 85436 equivalent inhabitants.

\subsection{Design data for the proposed situation}

Table 2. Minimum percentages of reduction are under the Directive 91/271/EEC and the qualitative concentrations in the effluent according to the Romanian standards

\begin{tabular}{|c|c|c|c|}
\hline \multirow[b]{2}{*}{ Contaminants } & \multirow{2}{*}{$\begin{array}{c}\text { Minimum } \\
\text { percentages of } \\
\text { reduction (Directive } \\
\text { 91/271/EEC) [\%] }\end{array}$} & \multicolumn{2}{|c|}{ Discharge limit values } \\
\hline & & $\begin{array}{l}\text { Value } \\
{[\mathrm{mg} / \mathrm{l}]}\end{array}$ & Standard \\
\hline $\begin{array}{l}\text { Biochemical Oxygen Demand } \\
\text { BOD5 (CBO5) }\end{array}$ & $70-90$ & 25 & $\begin{array}{c}\text { STAS 656-82 } \\
\text { SR ISO 5815-98 } \\
\end{array}$ \\
\hline $\begin{array}{l}\text { Chemical Oxygen Demand } \\
\text { COD }(\mathrm{CCO})\end{array}$ & 75 & 125 & SR ISO 6060-96 \\
\hline Suspended Solids (SS) & 90 & 35 & STAS 6953-81 \\
\hline Nitrogen Total Kjeldahl (NTK) & $70-80$ & 10 & STAS 7312-83 \\
\hline Phosphorus Total (P) & 80 & 1 & SR EN 1189-99 \\
\hline
\end{tabular}

Required efficiency of wastewater treatment-calculated.

The required degree of BOD5 (CBO5) treatment

$$
d_{C B O 5}:=\frac{C_{i . C B O 5}-C_{e . C B O 5}}{C_{i . C B O 5}}
$$

The required degree of $\mathrm{COD}(\mathrm{CCO})$ treatment

$$
d_{C C O}:=\frac{C_{i . C C O}-C_{e . C C O}}{C_{i . C C O}}
$$

The required degree of solid suspensions treatment

$$
d_{M T C}:=\frac{C_{i . M T S}-C_{e . M T S}}{C_{i . M T S}}
$$


The required degree of total nitrogen treatment

$$
d_{N T}:=\frac{C_{i . N T}-C_{e . N T}}{C_{i . N T}}
$$

The required degree of total phosphor treatment

$$
d_{P T}:=\frac{C_{i . P T}-C_{e . P T}}{C_{i . P T}}
$$

\begin{tabular}{|c|c|c|c|c|c|c|}
\hline & \multicolumn{4}{|c|}{ Inflow } & \multirow{2}{*}{$\begin{array}{c}\text { Effluent } \\
\mathrm{m}^{3} / \text { day } \\
\end{array}$} \\
\hline & & $\mathrm{m}^{3} /$ day & $\mathrm{m}^{3} /$ hour & $1 / \mathrm{sec}$ & $\mathrm{m}^{3} / \mathrm{sec}$ & \\
\hline Average daily flow & $\mathrm{Q}_{\text {zi med }}$ & 18857 & 785.7 & 218.3 & 0.22 & 18857 \\
\hline Maximum daily flow & $\mathrm{Q}_{\text {zi max }}$ & 24180 & 1008 & 279.9 & 0.28 & \\
\hline $\begin{array}{l}\text { Maximum hourlyflow - } \\
\text { on dry weather }\end{array}$ & $\mathrm{Q}_{\text {or max u }}$ & & 1322 & 367.2 & 0.37 & \\
\hline $\begin{array}{l}\text { Maximum used hourly } \\
\text { flow - in rainy weather }\end{array}$ & $\mathrm{Q}_{\text {or max pl }}$ & & 1661 & 461.4 & 0.46 & \\
\hline Minimum hourly flow & $Q_{\text {or minim }}$ & & 301 & 83.6 & 0.08 & \\
\hline Peak load factor & & 1.68 & & & & \\
\hline
\end{tabular}

Table 3. Flow rates in the Vaslui waste water treatment plant

Table 4. The parameter of water, to the inflow, in the Vaslui waste water treatment

\begin{tabular}{|l|c|c|}
\hline \multicolumn{1}{|c|}{ Parameter } & U.M. & Value \\
\hline Alkalinity & $(\mathrm{mmol} / \mathrm{l})$ & $>12$ \\
\hline $\mathrm{pH}$ & - & $6,5-8,5$ \\
\hline Temperature & $\left({ }^{\circ} \mathrm{C}\right)$ & $10-25$ \\
\hline
\end{tabular}

Table 5. Concentrations of contaminants, specific to a 24 hour average, in the Vaslui waste water treatment plant

\begin{tabular}{|l|c|c|c|c|}
\hline \multicolumn{1}{|c|}{ Contaminants } & $\begin{array}{c}\text { Amount of } \\
\text { Pollutants } \\
{[\mathbf{k g} / \mathbf{d a y}]}\end{array}$ & $\begin{array}{c}\text { Inflow } \\
\text { Concentration } \\
{[\mathbf{m g} / \mathbf{l}]}\end{array}$ & $\begin{array}{c}\text { Effluent } \\
\text { [mg/l] }\end{array}$ & $\begin{array}{c}\text { Percentages } \\
\text { of reduction } \\
{[\%]}\end{array}$ \\
\hline $\mathrm{CBO}_{5}\left(\mathrm{BOD}_{5}\right)$ & 5126 & 212 & 25 & 88,21 \\
\hline COD (CCO) & 10277 & 425 & 100 & 76,47 \\
\hline Suspended Solids (SS) & 5489 & 227 & 20 & 91,19 \\
\hline $\begin{array}{l}\text { Total Nitrogen } \\
\text { Kjeldhal (TKN) }\end{array}$ & 1209 & 50 & 10 & 80,00 \\
\hline $\begin{array}{c}\text { Ammonia Nitrogen } \\
\text { (NH4-N) }\end{array}$ & 846 & 35 & 0 & 100,00 \\
\hline Organic Nitrogen & 363 & 15 & 2 & 86,67 \\
\hline Phosphorus Total (P) & 169 & 7 & 1 & 85,71 \\
\hline
\end{tabular}


Treatment scheme chosen corresponds to characteristic wastewater flows and pollutant loads being achieved the following:

- On water treatment pathway: retention of suspended solids (SS), removal of biodegradable organic substances (BOD5), nutrient removal (phosphorus and nitrogen compounds) (Figure 3);

- On sludge treatment pathway: thickening, anaerobic stabilization, dehydration of sludge (Figure 4).

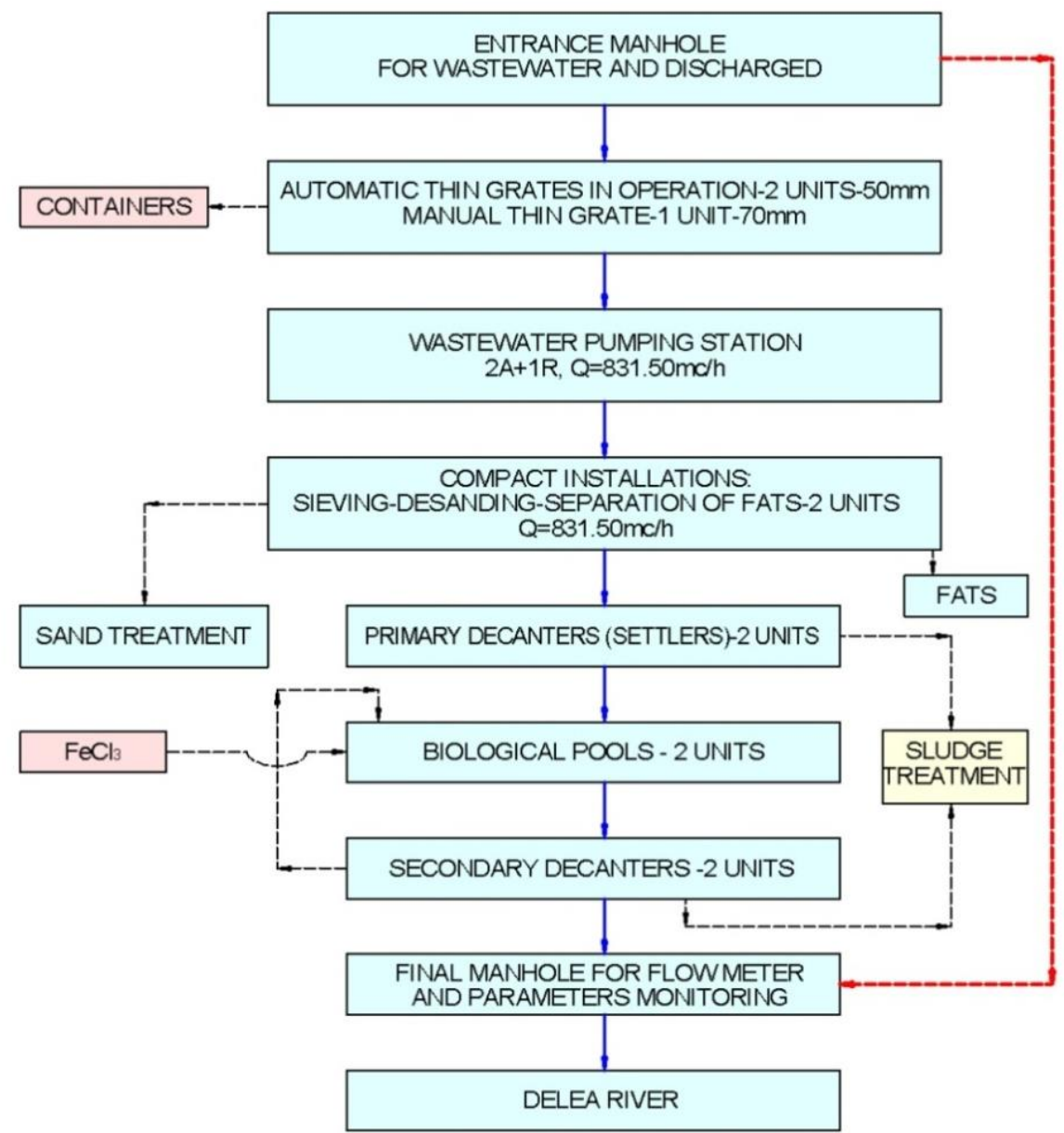

Fig.3. Water treatment pathway

\subsection{Process flow diagram}

This project includes the following works for wastewater treatment plant:

- creating a new mechanical treatment stage; 
- construction of a new biological treatment stage;

- creating a new sludge treatment stage;

- for monitoring waste water pumping station has been provided an automatic system (SCADA).

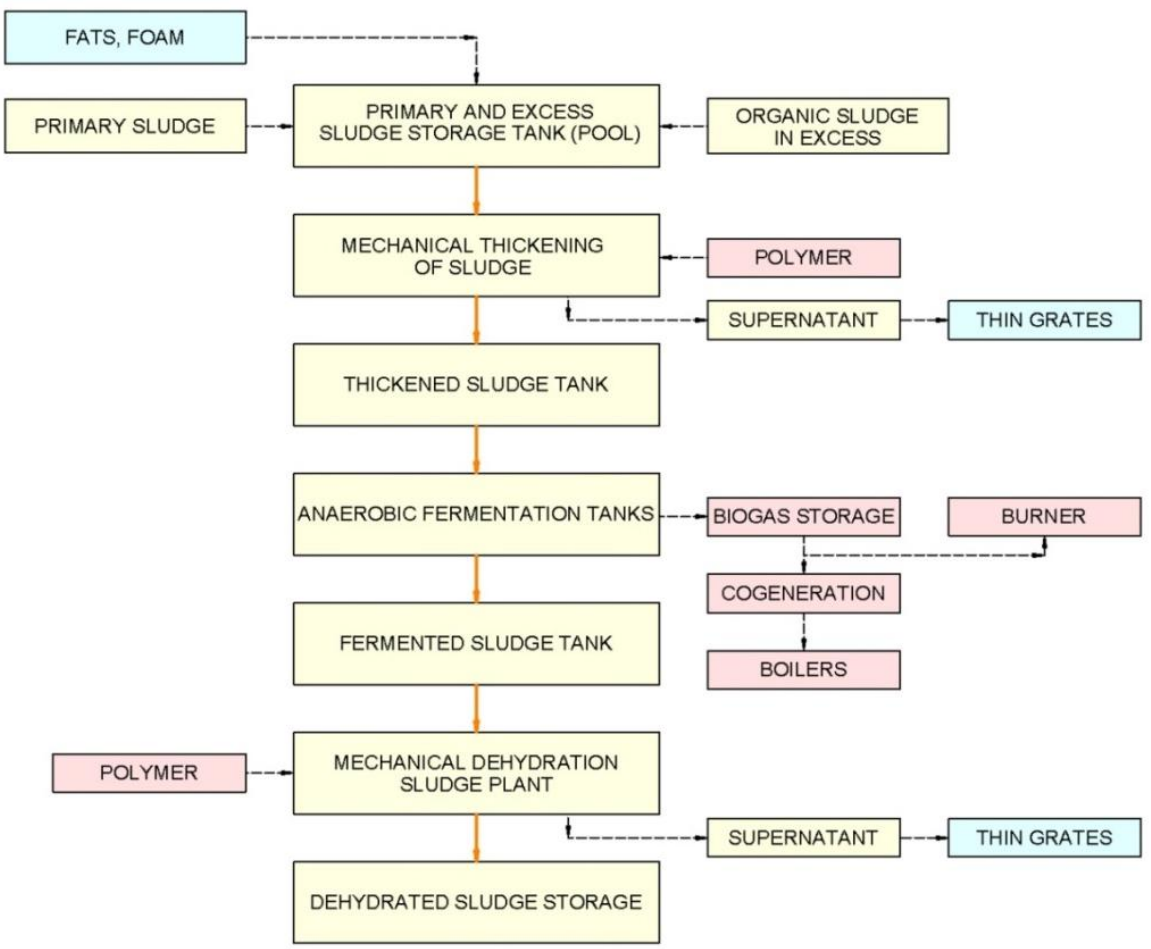

Fig.4. Sludge treatment pathway

\section{ENVIRONMENTAL IMPACTS ASSESSMENT AND MONITORING}

\subsection{General}

Sources of pollution that may affect the quality of the environment factors from the wastewater treatment activity are:

- domestic wastewater: malfunction may occur, at the wastewater treatment plant level, that if are not remedied in time will result in inefficient treatment of wastewater discharged.

Project implementation will not affect the quality of surface waters. By building the wastewater treatment plant, surface water quality and groundwater will improve and thus will be achieved a high degree of comfort for inhabitants. Vaslui WWTP will provide the framing of treated wastewater discharged parameters into the 
74 Ovidius University Annals Series: Civil Engineering, Issue 19, 2017

environment to the maximum permissible limit, according to HG 352/2005, NTPA $001 / 2005$.

- odors from the WWTP: given the fact that the wastewater treatment plant is covered, we consider the effect on the atmospheric air and the surrounding population is very small. However, it is required regular cleaning measures of wastewater treatment plant. Also, the platform of temporary storage of sludge shall be protected by a shed, tightly closed, to prevent the spread of odors into the atmosphere.

- materials from mechanical treatment: are represented by solid objects retained after mechanical wastewater treatment.

The first attempt to assess the environmental impacts was done within the Environment Study. Using the basic data from this Study, following the general recommendations for elaboration of the environmental impacts, using updated information and large amount of new data and taking into consideration all media and their interaction, detailed Environmental Impact Study was prepared.

In order to assess in more details possible impacts during construction, operation phase and post operation phase or some changes which are planned in the view of capacity or technology, of the access roads, main collectors and the WWTP, following phases and activities have been taken in consideration:

\subsubsection{Construction phase}

- Construction of the access roads and main collectors;

- Preparatory works at the location of the WWTP (material removal and flattening of the location) and excavation works;

- Transport and disposal of surplus excavated material;

- Construction of the structures of the WWTP (civil works, use of heavy machinery and vehicles);

- Disposal of construction waste;

-Installation of the equipment;

- Construction of accommodation facilities for the workers (water supply, sewerage, waste disposal).

\subsubsection{Operation phase}

- Treatment technology/ operation of the equipment for sewerage treatment and effluent production;

- Operation of equipment for sludge production (digester, drying beds and biogas production);

- Sludge (with dangerous substances) disposal on temporary storage at WWTP site.

\subsubsection{Post operation phase}

In the construction and operational phases, three main groups of environmental elements were analyzed, possible impacts were identified and mitigation measures were proposed. The following environmental elements were analyzed: 
- Natural Environment: Topography and geology (including ground subsidence); Water quality: Groundwater, Surface water/River water quality (including bottom sediment); Hydrology of River Delea; Biodiversity/ flora and fauna; Air quality (including meteorology); Landscape and visual effects; and Water use.

- Social Environment: Involuntary resettlement and Land acquisition; Livelihood and local economy; Institutions as local decision-making; Public infrastructure and services; Misdistribution of benefits and loss/damage; Local conflicts of interest; Archaeological and cultural heritage; Health and safety (including infectious diseases).

- Public hazards: Noise and vibration; Waste; Soil pollution.

Potential impacts on environmental components and measures to mitigate them.

The impacts are assessed using qualitative assessment of the following parameters:

Type: Positive (+); Negative (-);

Magnitude: A - large, B-medium, and C-low;

Extent: Local impact (at the site); wider impact (in the surrounding area);

Duration: Permanent impact; Temporary impact;

Timing: Immediate; Delayed Reversibility: Reversible; Irreversible.

In this paper, the emphasis is given to the impacts and mitigation measures related to water resources in construction and operational phase.

\section{CONCLUSIONS}

Romania has taken important steps in recent years to implement the Directive 91/271/EEC concerning urban wastewater treatment, both in terms of legislation and of consolidation the institutional framework for implementation.

In 2011 have been identified 511 treatment plants of which only 16 treatment plants were in compliance with the requirements of Directive 91/271/EEC, for the second stage of waste water treatment.

Because Vaslui is one of the 495 treatment plants compliant with the Directive it was decided that this station to receive funds for rehabilitation and modernization.

The waste water treatment plant it was sized for a capacity of 85436 equivalent inhabitants. Most existing targets of the station will be demolished leaving space of more efficient equipment. This station will also benefit from the introduction of tertiary waste water treatment stage.

After the calculations it can be seen that the maximum observed effluent concentrations of contaminants are respected in compliance with Romanian standards.

Following Table 5 "Concentrations of contaminants, specific to a 24 hour average, in the Vaslui waste water treatment plant", it can be observe that for the achievement of the minimum percentage of reduction according to the Directive 91/271/EEC, the effluent value should be decreased from $35 \mathrm{mg} / \mathrm{l}$ to $20 \mathrm{mg} / \mathrm{l}$ for the suspended solids, and from $125 \mathrm{mg} / \mathrm{l}$ to $100 \mathrm{mg} / \mathrm{l}$ for the COD respectively. 
In the next will be presents the major negative and positive impacts from the construction and operation of the WWTP and the main collectors on the water resources.

\subsection{Construction Phase}

\subsubsection{Negative Impacts:}

- Large disturbances of the groundwater table can be expected during the excavation works on the WWTP facilities that could result in disruptions of supply of the local wells which are used for domestic water supply or irrigation.

- Different river diversions structures will change the river bed morphology temporarily but the impact could rather high. With these structures, there will be impact on the river flow direction, while the river discharges will stay unchanged.

\subsection{Operational Phase}

\subsubsection{Positive Impacts:}

- In general, operation of the WWTP will have large positive impact on the quality of the water, the bottom sediment and the most of all on the water quality of the Delea River;

- The operation of the WWTP will have positive impact on the restoration and maintaining of the aquatic fauna in the Delea River;

- There are large positive impacts on the Social Environment elements: improved water supply of the downstream populated areas due to good quality of the surface water, and improved health of the downstream population as a result of the improved quality of drinking water.

\subsubsection{Negative Impacts:}

- During the drying process of the sludge deposited on drying beds, there is a high risk of groundwater pollution as a result of leachate infiltration;

- There is high risk for soil pollution with substances due to leakages and infiltration of the leachate from the sludge with hazardous substances disposed on temporary storage at the WWTP site;

- Generation of large quantity of sludge provokes large negative impact on all media (soil, groundwater, air, etc). Improper treatment of sludge could lead to putrefaction and other related problems such as bad odor, health effects etc.

- Generation of big quantity of sludge with hazardous substances can provoke large negative impact on all media (soil, groundwater, air, etc). In order to mitigate the negative impacts, extensive mitigation measures are proposed, described in details in above text. It is expected that with efficient application of these measures, there will be no large negative impacts on the water resources during construction and operation phase. Especially important measure is the recommendation for analyzing alternatives for sludge treatment and reduction of the quantities of sludge and to propose optimal solution according to the local conditions. 
The environmental impact assessment refers to determine the quality index values which have the following meanings:

- $\quad$ surface waters and aquifers will not be significantly affected, given the fact that we expect an improvement in water quality;

- soil and subsoil, will not suffer a significant impact, and it will be only on the limited period of time in the construction phase, considering that on the site the anthropic pressure was carried before;

- air will be affected, mainly by the possible odors from the waste water treatment plant;

- biodiversity will not suffer a significant impact considering the low natural value of the site analyzed, and the fact that the minimum protection measures will ensure the integrity of the area in terms of biodiversity;

- human settlements will be favored by the project, because this investment achievement will increase the health and comfort of population and will give new jobs for the population of the area.

The monitoring operation involves the following tasks:

- supervising the activities with the main objective to minimize the impact of this activity on the environment;

- a periodical control, with a proper frequency that follow how local authorities, during the collection, treatment and disposal of treated wastewater, conforms.

- the employees of the Vaslui WWTP are considering the proper operation of the station, and any malfunction must be remedied quickly.

- the technical inspection of the station will be made periodically.

To increase the hygiene conditions, comfort and safety of people and to protect the soil, subsoil, surface water and groundwater as well as the atmospheric air, measures are necessary to achieve a network of wastewater collection and their treatment in an efficient waste water treatment plant for a capacity of 85436 equivalent inhabitants.

\section{REFERENCES}

[1] Negulescu, M. - Epurarea apelor uzate orășenești, Editura Tehnică București, 1988;

[2] Perju, S. - Stații de pompare în sisteme de alimentări cu apă și canalizări, EdituraCONPRESS, București, 2009;

[3] Council Directive 91/271/EEC of 21 May 1991 concerning urban waste water treatment amended and completed by Commission Directive 98/15/EC on February 27, 1998

[4] DIN EN ISO 10628 - Flow diagram for process plants - General rules (ISO 10628:1997)

[5] European Union Directive 2000/60/EC Framework on October 23, 2000

[6] Government Decision no.188/2002 to approve the norms regarding wastewater discharge into the aquatic environment, amended and completed by Government Decision no. 352/2005 
[7] http://www.rowater.ro/TEST/Brosura-ape-uzate-pentru-public-2012.pdf, Situation of waste waters and urban sewage sludge from waste water treatment plants in Romania - Brochure for Public - Ministry of Environment and Forests and the "Romanian Waters "National Administration ,Bucharest, December2012 